\title{
RELATIONSHIP BETWEEN PHYTOPLANKTON FUNCTIONAL GROUPS AND ENVIRONMENTAL FACTORS IN THE HARBIN SECTION OF SONGHUA RIVER, NORTHEAST CHINA
}

\author{
ZHAO, F. ${ }^{1,2}-$ SUN, X. ${ }^{1}-$ LIU, D. ${ }^{1}-$ ShANG, L. Y. ${ }^{1}-$ LIU, J. M. ${ }^{1}-$ LI, X. Y. ${ }^{1}-$ LI, S. ${ }^{1}-$ LI, X. C. ${ }^{1}-$ \\ WANG, Y. Z. ${ }^{2}-$ SU, L. J. ${ }^{2}-$ ZHANG, L. M. ${ }^{2}-$ MU, Y. Y. ${ }^{2}-$ XIAO, L. ${ }^{2}-$ TIAN, Z. ${ }^{2}-$ PAN, C. $^{2}-$ \\ SUN, B. ${ }^{2}-$ PAN, H. F. ${ }^{3}-$ SHANG, G. Y. Q. ${ }^{4}-$ YU, H. X. ${ }^{1 *}-$ MA, C. X. ${ }^{*}$ \\ ${ }^{1}$ Department of Ecology, College of Wildlife and Protected Area, Northeast Forestry University, \\ Harbin 150040, China \\ (e-mail: iamzhaofei@foxmail.com-F.Zhao)
}

${ }^{2}$ The Water Ecology Laboratory, Hydrology and Water Resources Survey Station in Harbin, Harbin 150028, China

${ }^{3}$ Greater Khingan Ling Survey, Planning and Design Institute, National Forestry and Grassland Administration, Jagdaqi 16500, China

${ }^{4}$ B1 West Building, WF Central, Building 1, 269 Wangfujing Street, Dongcheng District, Beijing 100006, China

${ }^{5}$ School of Management,Heilongjiang University of Science and Technology, Harbin 150020, China (phone: +86-150-4586-2146)

*Corresponding author

e-mail/phone: china.yhx@163.com/+86-131-0096-0911 (H.X.Yu); mch007@vip.163.com/+86-180-

0366-8291 (C. X. Ma)

(Received $17^{\text {th }}$ Feb 2020; accepted $2^{\text {nd }}$ Jul 2020)

\begin{abstract}
In this study, samples were collected from 8 sites in the Harbin section of Songhua River, northeast China. We aimed to analyze how phytoplankton functional groups and environmental factors change from May to October during 2018. We identified 16 functional groups (C, D, F, G, H1, J, L0, MP, P, S1, TB, W1, W2, X1, X2 and $\mathrm{Y})$ from 84 species and 7 (C, D, MP, W1, W2, X1 and X2) of them were dominant. The seasonal succession of dominant phytoplankton functional groups was the following: $\mathrm{X} 2 / \mathrm{C} \rightarrow \mathrm{X} 2 / \mathrm{C} / \mathrm{MP} \rightarrow \mathrm{X} 2 / \mathrm{C} / \mathrm{X} 1 / \mathrm{MP} . \mathrm{X} 2$ and $\mathrm{C}$ always played a dominant role throughout the year. Results of the one-way ANOVA test and RDA revealed that WT, SD, NTU, Chl-a, DO, BOD5, NH4+, TP and Fe3 + were the major influencing factors. This study revealed that the dominant functional groups were positively correlated with SD and Chl-a and negatively correlated with NTU and TP.
\end{abstract}

Keywords: phytoplankton functional groups, environmental factors, Songhua River, RDA, spatial and seasonal variation, biomass

\section{Introduction}

Phytoplanktons are microbes that provide the foundation for aquatic food chains, and include zooplankton, fish and other aquatic animals in water environments and most important biological component in the River ecosystem. As a key part of material circulation and energy conversion in river ecosystem, phytoplankton has a very important impact on the status of aquatic ecosystem (Qiu et al., 2012). Meanwhile, phytoplankton function groups are communities of phytoplankton with similar functions in aquatic ecosystems (Reynolds et al., 2006; Crossetti et al., 2013; Huszaret al., 2015; Qu et al., 2019). It could be more directly described the growth of different species within a group in phytoplankton communities 
through the relatively simple classification of phytoplankton groups with observed data (Maggio et al., 2016). At present, Several studies have reflected the responsiveness of phytoplankton to environmental abiotic factors (Kruk et al., 2002; Bohnenberger et al., 2018), including water temperature (Hong et al., 2014), acidity (Klug et al., 2001), water level fluctuations (Su et al., 2019), total phosphorus and dissolved carbon (Klug et al., 2001), nutrient loading (Cupertino et al., 2019), etc. In addition, phytoplankton community development is influenced by the inter-specific interaction of organisms (Kim et al., 2020). However, most previous studies on phytoplankton functional groups had focused on the effects of a single environmental factor or a few species in a phytoplankton communities (Wang et al., 2020). The coexistence and succession of different phytoplankton functional groups under the same or similar environmental conditions have not been fully explained. The seasonal variation of environmental and biological factors are quite dynamic, they have a cumulative effect on different phytoplankton functional groups uccessions (Chuo et al., 2019). As such, more research is needed to quantify the interactions of stress effects of different factors on aquatic organisms in the future. This study can also meet the growing demand for sustainable watershed management of aquatic biota.

Songhua River, one of the 7 largest rivers in China, is the largest river in Heilongiiang Province and one of the key monitoring regions of the aquatic biodiversity conservation in China. According to the Xinhua News Agency, Songhua River of 1,900-km-long meanders through an area of 557,200 $\mathrm{km}^{2}$, spanning Jilin Province and Heilongjiang Province, northeast China. According to the topography and channel characteristics, Songhua River is divided into three sections: the upper, middle and lower reaches. Harbin section of Songhua River is located in the middle reaches of the Songhua River. Harbin section of Songhua River starts from Sanjiazi in the upper reaches and ends at Dadingzi mountain in the lower reaches. There are two first grade tributaries, Ashi River and Hulan River. Along the Songhua River, there are Sanjiazitan wetland, Yangmingtan wetland, Jinhewan Wetland Park, Hulan estuary wetland park and other wetland parks. Songhua River would not only meet the domestic water demand of Harbin's industry and its people but also meet the ecological demand of landscape. Therefore, in order to ensure the healthy and sustainable development of the water ecological environment in the Harbin section of Songhua River, it is particularly important to investigate the changes of phytoplankton functional groups and analyze the relationship between phytoplankton functional groups and water environmental factors.

In this study, we monitored and calculated the biomass of the phytoplankton functional groups and the related water environmental factors in 2018. we analyzed the interaction between phytoplankton functional group and water environmental factors by redundancy analysis (RDA). This paper puts forward the experimental data support for the water environmental ecosystem and sustainable development of water resources of Songhua River, northeast China.

\section{Materials and methods}

\section{Field sampling and measurements}

According to the local climate and geographical characteristics, we investigated on the phytoplankton in the Harbin section of Songhua River, Heilongjaing Province, northeast China. Samples were collected seasonally (spring: May 8, 2018; summer: July 20, 2018; autumn: October 9, 2018) at eight sampling stations (Fig. 1; Table 1), respectively. Water samples were collected from 9:00 am to 5:00 bm. 


$$
\text { - } 5761 \text { - }
$$
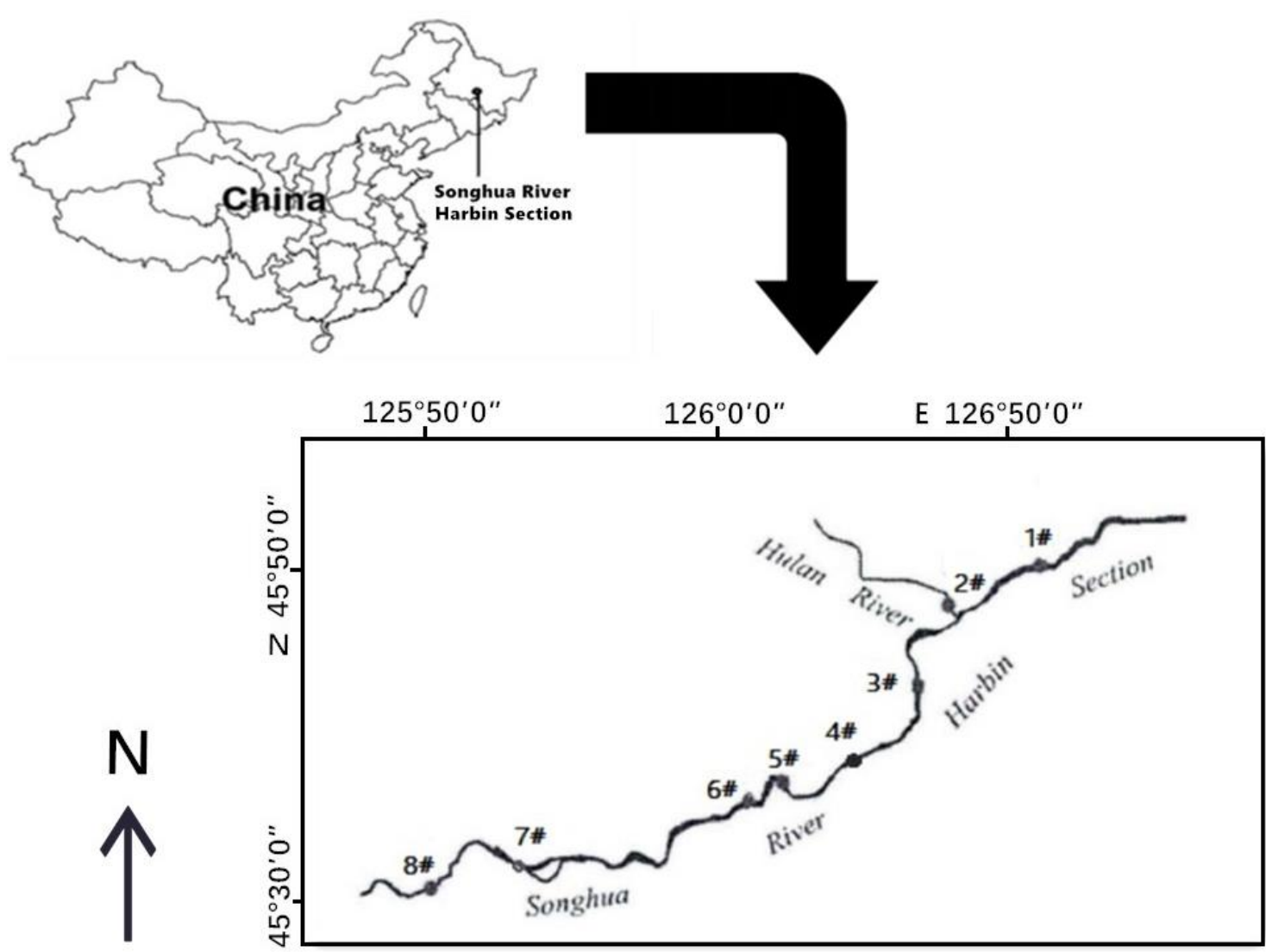

Figure 1. The sampling stations in the Harbin section of Songhua River, Northeast China

Table 1. The number, GPS and water depth of each sampling station in the Harbin section of Songhua River, Northeast China

\begin{tabular}{|c|c|c|c|c|c|}
\hline \multirow{2}{*}{ Number } & \multirow{2}{*}{ Station } & \multirow{2}{*}{ GPS } & \multicolumn{3}{|c|}{ Water depth (m) } \\
\hline & & & Spring & Summer & Autumn \\
\hline $1 \#$ & Daliangzi village & $\begin{array}{l}\mathrm{N}: 45^{\circ} 58^{\prime} 30^{\prime \prime} \\
\mathrm{E}: 126^{\circ} 51^{\prime} 39^{\prime \prime}\end{array}$ & 4.50 & 8.30 & 26.80 \\
\hline $2 \#$ & Hulan estuary wetland park & $\begin{array}{l}\mathrm{N}: 45^{\circ} 55^{\prime} 28^{\prime \prime} \\
\mathrm{E}: 126^{\circ} 47^{\prime} 20^{\prime \prime}\end{array}$ & 3.30 & 9.00 & 5.70 \\
\hline $3 \#$ & Sanjiazitan wetland & $\begin{array}{l}\mathrm{N}: 45^{\circ} 54^{\prime} 40^{\prime \prime} \\
\mathrm{E}: 126^{\circ} 45^{\prime} 52^{\prime \prime}\end{array}$ & 7.50 & 3.50 & 4.50 \\
\hline $4 \#$ & Cement plant & $\begin{array}{l}\mathrm{N}: 45^{\circ} 51^{\prime} 44^{\prime \prime} \\
\mathrm{E}: 126^{\circ} 42^{\prime} 23^{\prime \prime}\end{array}$ & 13.20 & 12.10 & 10.20 \\
\hline $5 \#$ & The second water source & $\begin{array}{l}\mathrm{N}: 45^{\circ} 45^{\prime} 23^{\prime \prime} \\
\mathrm{E}: 126^{\circ} 32^{\prime} 59^{\prime \prime}\end{array}$ & 9.80 & 11.70 & 12.70 \\
\hline $6 \#$ & Yangmingtan wetland & $\begin{array}{l}\mathrm{N}: 45^{\circ} 46^{\prime} 12^{\prime \prime} \\
\mathrm{E}: 126^{\circ} 31^{\prime} 13^{\prime \prime}\end{array}$ & 7.90 & 15.30 & 13.70 \\
\hline 7\# & Jinhewan wetland park & $\begin{array}{l}\mathrm{N}: 45^{\circ} 46^{\prime} 10^{\prime \prime} \\
\mathrm{E}: 126^{\circ} 28^{\prime} 55^{\prime \prime}\end{array}$ & 2.50 & 3.10 & 2.20 \\
\hline $8 \#$ & Sanjiazi village & $\begin{array}{l}\mathrm{N}: 45^{\circ} 32^{\prime} 23^{\prime \prime} \\
\mathrm{E}: 125^{\circ} 53^{\prime} 11^{\prime \prime}\end{array}$ & 1.30 & 5.50 & 1.80 \\
\hline
\end{tabular}




\section{Sample collection and determination}

Phytoplankton samples were collected with a 5-L water sampler, and mixed samples of the upper water layer, the mid-water layer and the bottom water layer. Integrated $1000 \mathrm{~mL}$ water samples were preserved with acid Lugol iodine solution immediately and stored in the dark. Water sample was Siphoned to $30 \mathrm{~mL}$ into polythene plastic bottle after $48 \mathrm{~h}$. And then qualitative and quantitative analysis was performed with 40 times magnification by optical microscope (Motic BA210, Motic Inc., China) $(\mathrm{V}=0.1 \mathrm{~mL}$ ) (Utermöhl, 1958). Phytoplankton species were identified using the references s from different literature (Hustedt, 1930; Prescott, 1954; Patrick et al., 1966; Komarek, 1983; Lange-Bertalot, 2001; Hu et al., 2006). The species were grouped into functional group as described by literature of science (Reynolds et al.; 2002; Reynolds, 2006; Padisak et al., 2009).

Transparency (SD) was estimated with a $20-\mathrm{cm}$ diameter, black-white Secchi disc. Water depth and Flow rate (FR) were measured with the LCD digital sounder (HONDEX PS-7, HONDEX Inc., Japan) and hand-held current meter of YSI (YSI FlowTracker, YSI Inc., USA), respectively. Water temperature (WT) was measured with thermometer. PH, turbidity (NTU) and dissolved oxygen (DO) were recorded realtime by a multi-parameter water quality sonde (YSI 6600, YSI Inc., USA). Chlorophyll a $(\mathrm{Chl}-\mathrm{a})$, potassium permanganate index $\left(\mathrm{COD}_{\mathrm{Mn}}\right)$, chemical oxygen demand $\left(\mathrm{COD}_{\mathrm{Cr}}\right)$, 5-day biochemical oxygen demand $\left(\mathrm{BOD}_{5}\right)$, ammonium nitrogen $\left(\mathrm{NH}_{4}^{+}\right)$, total phosphorus (TP), total nitrogen (TN), fecal coliform (FC), and $\mathrm{Fe}^{3+}$ were checked and analyzed according to standard examine methods on drinking water (GB/T5750-2006) of the Chinese standard methods proposed by Ministry of Environmental Protection of People's Republic of China (MEP, 2006).

\section{Statistical analyses}

For this analysis, these phytoplankton species we selected were identified the dominant species $(y \geq 2)$ of the study period, and their relative abundance $>1$ at least in one sampling station (Xu et al., 1989; Lopes et al., 2005). The dominant species of phytoplankton (Y) was calculated by Equation 1 (Lampitt et al., 1993):

$$
Y=\left(\frac{n_{i}}{N}\right) f_{i}
$$

$n_{i}$ is an individual amount of the phytoplankton species, $N$ is the sum of all individual amount (Gafan et al., 2005), $f_{i}$ is the appearance frequency of the occurrence of $i$ species in all phytoplankton samples, $i$ is considered as the dominant species if $y \geq 0.02$.

We selected one-way analysis of covariance (ANCOVA) to establish the significant difference among physico-chemical characteristics during the study period, and the ordinations to run using computer program SPSS 16.0. All biomass data of functional groups and continuous environmental factors except for $\mathrm{pH}$ were $\log _{10}(\mathrm{X}+1)$ transformed to stabilize variance and reduce the influence of dominant taxa on the ordination and subjected to redundancy analysis (RDA) using down weighing of rare species (Jongman et al., 1987; ter Braak, 1988, 1990, 1994). Relationships between the phytoplankton functional groups and the environmental factors were assessed using redundancy analysis (RDA), which is a linear method of direct ordination. RDA was performed using CANOCO for Windows 4.5 (ter Braak et al., 1998), with forward selection to 
identify the environmental variables that explained the phytoplankton functional groups, which is a linear method of direct ordination (ter Braak, 1994). The significance of the variables and the first ordination axis was determined using Monte Carlo permutation testing (499 permutations), implemented in CANOCO.

This kind of technique can perform both regression and data ordination concurrently. The significance of the correlations between environmental factors and the species distribution was tested by one-way ANOVA test and redundancy analysis (RDA). Environmental factors measurement included WT $\left({ }^{\circ} \mathrm{C}\right), \mathrm{pH}, \mathrm{FR}(\mathrm{m} / \mathrm{s}), \mathrm{SD}(\mathrm{cm})$, turbidity (NTU), DO (mg/L), Chl-a/ (ug/L), COD $\mathrm{Mn}(\mathrm{mg} / \mathrm{L}), \mathrm{COD}_{\mathrm{Cr}}(\mathrm{mg} / \mathrm{L}), \mathrm{BOD}_{5}$ $(\mathrm{mg} / \mathrm{L}), \mathrm{NH}_{4}{ }^{+}(\mathrm{mg} / \mathrm{L}), \mathrm{TP}(\mathrm{mg} / \mathrm{L}), \mathrm{TN}(\mathrm{mg} / \mathrm{L}), \mathrm{FC}(\mathrm{mg} / \mathrm{L}), \mathrm{Fe}^{3+}(\mathrm{mg} / \mathrm{L})$. Only the samples which most environmental data were used in the RDA analysis to study the correlations with environmental factors on phytoplankton distribution.

\section{Results}

\section{Characteristics of phytoplankton functional groups}

A total of 84 species of phytoplankton were identified in the 24 samples collected from Harbin section of Songhua River, northeast China, belonging to 6 phyla, 8 classes, 15 orders, 26 families and 50 genera. Among these species, 37 belong to Chlorophyta, 29 belong to Bacillariophyta, and 9 belong to Cyanophyta, which represent approximately $44 \%, 35 \%$, and $11 \%$ of the total species, respectively. In addition, the samples included six species in Euglenophyta (7\%), two species in Cryptophyta (2\%), and one species in Dinophyta (1\%). And then classified into 16 functional groups namely: C, D, F, G, H1, J, L0, MP, P, S1, TB, W1, W2, X1, X2, Y (Table 2). There were 4 important functional groups, which with relative biomass $>20 \%$ at each sampling stations: C, MP, X2, Y. And there were 7 dominant function groups: C, D, $\mathrm{MP}, \mathrm{W} 1, \mathrm{~W} 2, \mathrm{X} 1, \mathrm{X} 2$ (Table 3). The seasonal relative biomass of functional groups in this study, $\mathrm{X} 2$ and $\mathrm{C}$ were dominant at $38.30 \%$ and $29.68 \%$ in spring, respectively; $\mathrm{X} 2$, $\mathrm{C}$ and MP were dominant at $40.97 \%, 15.87 \%$ and $13.20 \%$ in summer, respectively; X2, C, X1 and MP were dominant at $47.53 \%, 12.92 \%, 10.70 \%$ and $10.51 \%$ in autumn, respectively. It could be seen $\mathrm{X} 2$ and $\mathrm{C}$ were dominant in this year. In particular, $\mathrm{X} 2>50 \%$ in $2 \#$ and $3 \#$ of spring, 2\# of summer, 1\#,3\# and 7\# of autumn, respectively. The distribution variation of phytoplankton functional groups is shown in Figure 2. Phytoplankton abundance was $(407.40-767.40) \times 10^{4}$ ind./L and its mean was $524.10 \times 10^{4}$ ind./L in spring; it was $(51.00-156.60) \times 10^{4}$ ind./L and its mean was $88.95 \times 10^{4}$ cell/L in summer; it was $(69.60-184.80) \times 10^{4}$ cell/L and its mean was $119.03 \times 10^{4}$ cell// $\mathrm{L}$ in autumn. Biomass ranged from 3.06 to $5.10 \mathrm{mg} / \mathrm{L}$ and its mean was $3.85 \mathrm{mg} / \mathrm{L}$ in spring; it ranged from 0.45 to $1.34 \mathrm{mg} / \mathrm{L}$ and its mean was $0.79 \mathrm{mg} / \mathrm{L}$ in summer; it ranged from 0.50 to $1.79 \mathrm{mg} / \mathrm{L}$ and its mean was $1.02 \mathrm{mg} / \mathrm{L}$ in autumn.

\section{Environmental variables}

The average concentration of physico-chemical characteristics of Songhua River is shown in Table 4 . WT ranged between $13.60-23.37{ }^{\circ} \mathrm{C}$ with maximum in summer and minimum in spring. WT showed distinguishing seasonal differences $(\mathrm{p}<0.001)$ which were higher in summer and relatively lower in autumn. On the contrary, SD ranged between 10.50-58.50 $\mathrm{cm}$ with maximum in spring and minimum in summer. SD differed significantly seasonally $(p<0.001)$ with higher significant values in spring than 
in summer and autumn. NTU ranged between 7.55-170.30 with maximum in summer and minimum in spring. The river's NTU also varied seasonally $(\mathrm{p}<0.001)$ with summer recording the highest values. The Chl-a ranged between 0.45-21.10 with maximum in spring and minimum in autumn. Chl-a differed with higher significant values $(p<0.001)$ in spring than in autumn. DO ranged between 4.70-9.75 mg/L with lower significantly values $(\mathrm{p}<0.001)$ in summer than in spring and autumn. BOD 5 was significantly higher in spring and relatively lower in autumn $(\mathrm{p}<0.001) . \mathrm{NH}_{4}{ }^{+}$ranged between $0.07-0.83 \mathrm{mg} / \mathrm{L}$ with lower significantly values $(\mathrm{p}<0.001)$ in autumn than in spring and summer. On the contrary, total phosphorus (TP) ranged between 0.04$0.19 \mathrm{mg} / \mathrm{L}$ with higher significantly values $(\mathrm{p}<0.001)$ in autumn than in spring and summer. $\mathrm{Fe}^{3+}$ ranged between $0.10-1.64 \mathrm{mg} / \mathrm{L}$ with lower significantly values $(\mathrm{p}<0.001)$ in spring than in summer and autumn.

Table 2. Phytoplankton functional groups (FGs) and their relative biomass (\%) in the Harbin section of Songhua River, Northeast China

\begin{tabular}{|c|c|c|}
\hline FGs & Genera & Biomass (\%) \\
\hline $\mathrm{C}$ & Asterionella formosa, Cyclotella meneghiniana & $24.73 \%$ \\
\hline $\mathrm{D}$ & $\begin{array}{c}\text { Nitzschia palea, Synedra acus, Synedra amphicephala, Synedra tabulata, } \\
\text { Synedra ulna }\end{array}$ & $3.24 \%$ \\
\hline $\mathrm{F}$ & $\begin{array}{c}\text { Oocystis parva, Oocystis elliptica, Micractinium pusillum, Kirchnerilla } \\
\text { lunaris, Selenastrum gracile, Westella botryoides, Westellopsis linearis, } \\
\text { Stichococcus bacillaris }\end{array}$ & $0.62 \%$ \\
\hline G & Eudorina elegans, Pandorina morum & $0.20 \%$ \\
\hline $\mathrm{H} 1$ & Anabaena variabilis, Anabaena circinalis & $0.01 \%$ \\
\hline $\mathrm{J}$ & $\begin{array}{l}\text { Golenkinia radiata, Chodatella quadriseta, Chodatella ciliata, Tetraëdron } \\
\text { trigonum, Tetraëdron regulare, Actinastrum hantzschii, Crucigenia aiculata, } \\
\text { Crucigenia quadrata, Crucigenia tetrapedia, Tetrastrum staurogeniae forme, } \\
\text { Tetrastrum elegans, Scenedesmus ovalternus, Scenedesmus platydiscus, } \\
\text { Scenedesmus dimorphus, Scenedesmus abundans, Scenedesmus acuminatus, } \\
\text { Scenedesmus bijuga, Scenedesmus quadricauda }\end{array}$ & $1.97 \%$ \\
\hline L0 & Gyrosigma acuminatum, Merismopedia minima, Chroococcus minutus & $0.06 \%$ \\
\hline MP & $\begin{array}{l}\text { Cocconeis placentula, Achnanthes linearis, Epithemia turgida var. granulata, } \\
\text { Surirella capronii, Surirella angustata, Cymbella ventricosa, Pinnularia } \\
\text { major, Pinnularia gibba, Navicula exigua, Navicula radiosa, Navicula } \\
\text { dicephala, Navicula anglica, Diatoma vulgare, Diatoma vulgare var. linearis, } \\
\text { Coelosphaerium kützingianum, Ulothris variabilis }\end{array}$ & $5.91 \%$ \\
\hline $\mathrm{P}$ & $\begin{array}{c}\text { Fragilaria virescens, Fragilaria brevistriata, Fragilaria ca pucina, Melosira } \\
\text { granulata, Melosira granulata var. angustissima, Melosira granulata var. } \\
\text { angustissima f. spiralis, Closterium sp. }\end{array}$ & $1.09 \%$ \\
\hline S1 & $\begin{array}{l}\text { Planktothrix agardhii, Phormidium allorgei, Phormidium beggiatoiforme, } \\
\text { Phormidium lismorense }\end{array}$ & $0.70 \%$ \\
\hline TB & Melosira varians & $1.59 \%$ \\
\hline W1 & $\begin{array}{l}\text { Heteronema discomorphum, Lepocinclis steinii, Euglena oxyuris, } \\
\text { Trachelomonas cylindrica, Strombomonas urceolata }\end{array}$ & $1.92 \%$ \\
\hline W2 & Trachelomonas granulosa & $2.35 \%$ \\
\hline $\mathrm{X} 1$ & $\begin{array}{c}\text { Ankistrodesmus angustus, Ankistrodesmus acicularis, Chlorella vulgaris, } \\
\text { Schroederia nitzschioides, Schroederia robusta }\end{array}$ & $7.73 \%$ \\
\hline $\mathrm{X} 2$ & Chlamydomonas ovalis, Chlamydomonas globosa, Chroomonas acuta & $40.34 \%$ \\
\hline $\mathrm{Y}$ & Glenodinium pulvisculus, Cryptomonas ovata & $7.53 \%$ \\
\hline
\end{tabular}




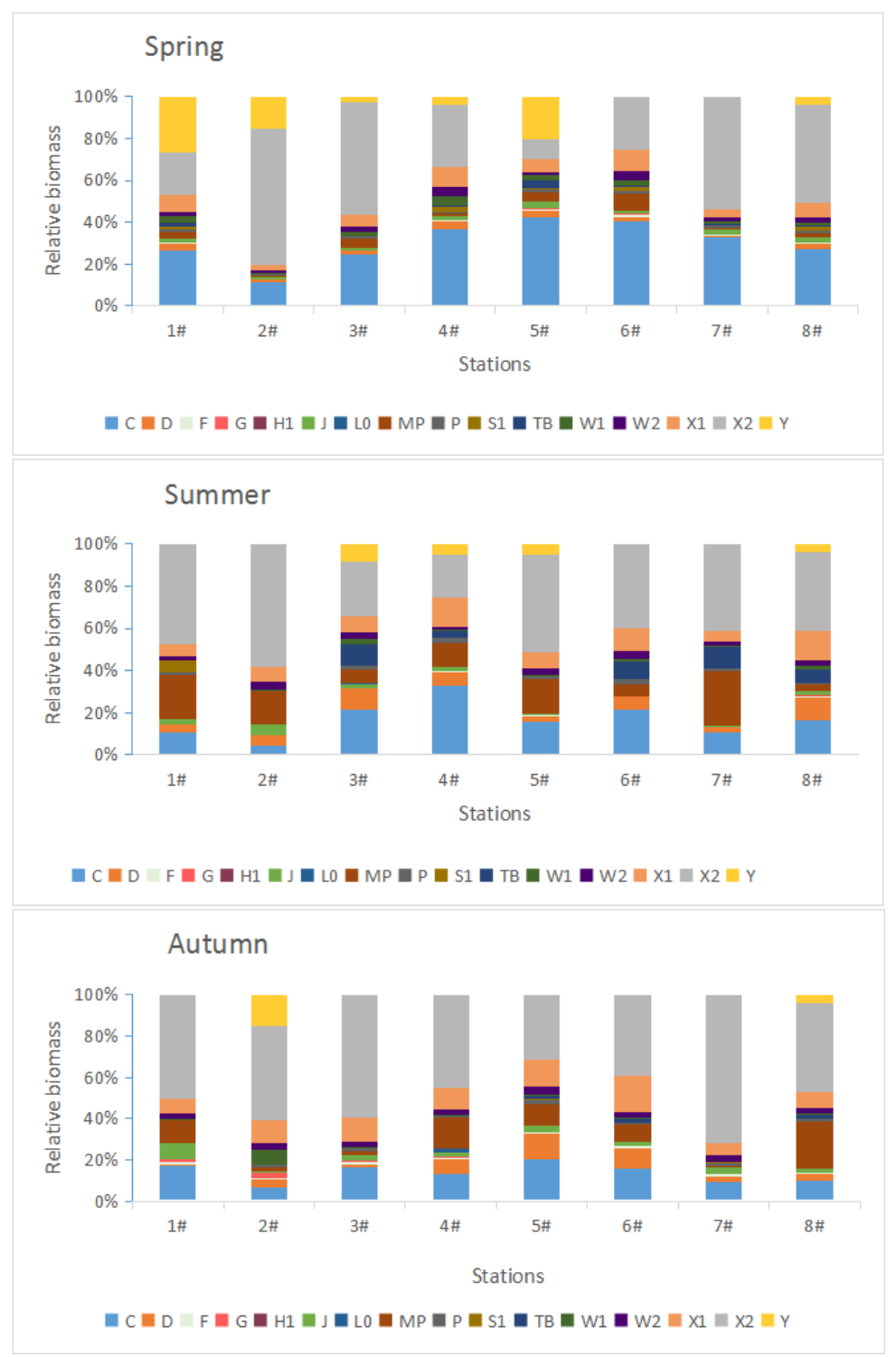

Figure 2. Distribution of relative biomass of phytoplankton functional groups in the Harbin section of Songhua River, Northeast China

Table 3. Appendix list of dominant genus of phytoplankton functional groups in the Harbin section of Songhua River, Northeast China

\begin{tabular}{c|c|c|c|c|c}
\hline \multirow{2}{*}{ FGs } & \multirow{2}{*}{ Phylum } & \multirow{2}{*}{ Genus } & \multicolumn{3}{|c}{ Dominance } \\
\cline { 4 - 6 } & & Spring & Summer & Autumn \\
\hline D & Bacillariophyta & Synedra acus & & 0.03 & 0.03 \\
C & Bacillariophyta & Cyclotella meneghiniana & 0.47 & 0.32 & 0.25 \\
W2 & Euglenophyta & Trachelomonas granulosa & 0.07 & 0.11 & 0.12 \\
W1 & Euglenophyta & Trachelomonas cylindrica & 0.08 & 0.04 & \\
X1 & Chlorophyta & Ankistrodesmus angustus & 0.03 & & \\
X1 & Chlorophyta & Chlorella vulgaris & 0.04 & 0.10 & 0.10 \\
MP & Chlorophyta & Ulothris variabilis & & & 0.05 \\
X2 & Chlorophyta & Chlamydomonas ovalis & & 0.02 & 0.03 \\
X2 & Cryptophyta & Chroomonas acuta & 0.08 & 0.11 & 0.11 \\
\hline
\end{tabular}


Table 4. Environmental parameters, which contained water temperature (WT), $\mathrm{pH}$, flow rate $(F R)$, Secchi depth (SD), turbidity (NTU), Chlorophyll a (Chl-a), dissolved oxygen (DO), Permanganate index $\left(C O D_{M n}\right)$, Chemical oxygen demand $\left(C O D_{C r}\right)$, 5-day biochemical oxygen demand $\left(\mathrm{BOD}_{5}\right), \mathrm{NH}_{4}{ }^{+}$, total phosphorus (TP), total nitrogen (TN), Fecal Coliform $(F C), \mathrm{Fe}^{3+}$, in each season in the Harbin section of Songhua River, Northeast China

\begin{tabular}{c|c|c|c|c}
\hline Parameters & Spring & Summer & Autumn & P value \\
\hline $\mathrm{WT}\left({ }^{\circ} \mathrm{C}\right)$ & $17.55 \pm 1.63$ & $22.9 \pm 0.45$ & $14.52 \pm 0.4$ & $0.000^{* *}$ \\
$\mathrm{pH}$ & $7.86 \pm 0.41$ & $7.59 \pm 0.18$ & $7.72 \pm 0.08$ & 0.142 \\
$\mathrm{FR}(\mathrm{m} / \mathrm{s})$ & $0.73 \pm 0.58$ & $0.97 \pm 0.36$ & $0.45 \pm 0.24$ & 0.070 \\
$\mathrm{SD}(\mathrm{m})$ & $37.5 \pm 10.27$ & $11.44 \pm 0.82$ & $18.5 \pm 3.97$ & $0.000^{* *}$ \\
$\mathrm{NTU}$ & $15.91 \pm 6.1$ & $141.01 \pm 26.9$ & $43.9 \pm 11.25$ & $0.000^{* *}$ \\
$\mathrm{Chl}-\mathrm{a}(\mathrm{ug} / \mathrm{L})$ & $14.27 \pm 6.94$ & $8.02 \pm 2.45$ & $5.98 \pm 2.42$ & $0.004 * *$ \\
$\mathrm{DO}(\mathrm{mg} / \mathrm{L})$ & $7.84 \pm 0.93$ & $6.6 \pm 1.17$ & $8.9 \pm 0.29$ & $0.000^{* *}$ \\
$\mathrm{COD}{ }_{\mathrm{Mn}}(\mathrm{mg} / \mathrm{L})$ & $5.56 \pm 1$ & $5.33 \pm 0.7$ & $4.65 \pm 0.55$ & 0.070 \\
$\mathrm{COD}(\mathrm{mg} / \mathrm{L})$ & $12.25 \pm 0.6$ & $13.08 \pm 1$ & $12.53 \pm 1.13$ & 0.217 \\
$\mathrm{BOD}_{5}(\mathrm{mg} / \mathrm{L})$ & $4.74 \pm 1.08$ & $2.96 \pm 0.8$ & $2.31 \pm 0.48$ & $0.000^{* *}$ \\
$\mathrm{NH}_{4}{ }^{+}(\mathrm{mg} / \mathrm{L})$ & $0.43 \pm 0.3$ & $0.18 \pm 0.11$ & $0.13 \pm 0.06$ & $0.010^{* *}$ \\
$\mathrm{TP}(\mathrm{mg} / \mathrm{L})$ & $0.07 \pm 0.03$ & $0.1 \pm 0.02$ & $0.15 \pm 0.03$ & $0.000^{* *}$ \\
$\mathrm{TN}^{(\mathrm{mg} / \mathrm{L})}$ & $2.05 \pm 0.79$ & $2.26 \pm 0.46$ & $1.83 \pm 0.11$ & 0.288 \\
$\mathrm{FC}(\mathrm{mg} / \mathrm{L})$ & $14050.25 \pm 11553.15$ & $26284.88 \pm 12806.46$ & $22707.88 \pm 12551.8$ & 0.149 \\
$\mathrm{Fe}^{3+}(\mathrm{mg} / \mathrm{L})$ & $0.19 \pm 0.07$ & $0.98 \pm 0.22$ & $1.23 \pm 0.49$ & $0.000^{* *}$ \\
\hline
\end{tabular}

**The environmental factors were significantly different at the level of 0.01

\section{Correlation analysis of phytoplankton functional groups and environmental factors}

The results of DCA performance by using CANOCO for Windows 4.5 showed that the Standard Deviation value was less than 3, so RDA analysis was carried out to analysis the relationship between phytoplankton functional groups and environmental factors in the Harbin section of Songhua River. The eigenvalue for RDA axis 1 (0.691) and axis $2(0.156)$ together explained $84.7 \%$ of the functional groups variance out of which $69.1 \%$ of the total variability was from axis 1 (Table 5). The results of Monte Carlo test revealed that there were significant differences between the first axes and all canonical axes $(\mathrm{F}=17.921, \mathrm{p}=0.0002, \mathrm{~F}=4.109, \mathrm{p}=0.004)$. Axis 1 mainly positive correlated with SD $(\mathrm{r}=0.8729), \mathrm{BOD}_{5}(\mathrm{r}=0.7026)$ and negatively correlated with $\mathrm{Fe}^{3+}$ $(\mathrm{r}=-0.8241)$, NTU $(\mathrm{r}=-0.8163)$. Axis 2 positively correlated with Chl-a $(\mathrm{r}=0.2453)$ and $\mathrm{COD}_{\mathrm{Mn}}(\mathrm{r}=0.2453)$ and negatively correlated with $\mathrm{NH}_{4}{ }^{+}(\mathrm{r}=-0.3812)$, TP $(\mathrm{r}=-$ $0.3112)$.

Table 5. Summary of redundancy analysis (RDA) of phytoplankton functional groups for the first two axes

\begin{tabular}{c|c|c|c|c}
\hline Axes & I & II & III & IV \\
\hline Eigenvalues & 0.691 & 0.156 & 0.027 & 0.008 \\
Species-environment correlations & 0.972 & 0.838 & 0.930 & 0.893 \\
Cumulative percentage variance of species data & 69.1 & 84.7 & 87.4 & 88.2 \\
Cumulative percentage variance of species-environment relation & 78.1 & 95.7 & 98.7 & 99.7 \\
Sum of all canonical eigenvalue & 0.885 & & & \\
\hline
\end{tabular}




\section{Discussion}

\section{Variation of phytoplankton functional groups in the Harbin section of Songhua River, Northeast China}

In previous studies, the use of classification of organisms into phytoplankton functional groups have been to be the best way to explain the influence relation between factors of phytoplankton community structure and aquatic systems (Heebert et al., 2016). The Padisak J's study also showed the changes of life-history and physiological activity of phytoplankton functional groups have limited by factors of nutrient, light condition, hydrodynamic character, foraging behavior of zooplnation and hydrology dynamic change characteristics (Padisak et al., 2009). In the recent past, phytoplankton functional groups based on the morphological, as the primary producer in aquatic ecosystem, is a reliable indicator to analysis on water environmental quality and illustrate the trend of spatial and temporal variations (Li et al., 2017). Many recently studies focused on the change trend of biomass of phytoplankton functional groups in relation to their surviving environment (Mwagona et al., 2018; Ma et al., 2019; Sun et al., 2019). During the study period, the average biomass of phytoplankton was $3.85 \mathrm{mg} / \mathrm{L}$ in spring, $0.79 \mathrm{mg} / \mathrm{L}$ in summer and $1.02 \mathrm{mg} / \mathrm{L}$ in autumn. The aforesaid experimental datum were lower compared to the datum of average biomass during spring $(4.03 \mathrm{mg} / \mathrm{L})$, summer $(2.78 \mathrm{mg} / \mathrm{L})$ and autumn $(5.07 \mathrm{mg} / \mathrm{L})$ recorded by Yan (2011) in the Harbin section of Songhua River, and also lower than those during summer $(2.30 \mathrm{mg} / \mathrm{L})$ and autumn $(2.57 \mathrm{mg} / \mathrm{L})$ of $\mathrm{Li}(2013)$ accepted for publication in the Harbin section of Songhua River. So far, the results showed that average biomass of phytoplankton reduce continuously.

Our research showed that the main dominant phytoplankton functional groups were group $\mathrm{C}$ and $\mathrm{X} 2$ in the whole year. The two phytoplankton functional groups which we investigated were also the dominant functional groups studied by An et al. in Small Xingkai Lake and by $\mathrm{Ma}$ et al. Sanhuanpao wetland reservation which located in the same province (An et al., 2016; Ma et al., 2016). Group C represents the eutrophic small and medium sized lakes, and it was suitable for the water environment of no stratification or suspension (Yang et al., 2014). According to Reynolds' phytoplankton functional group theory indicated, group X2, sensitive to the filtering food zooplankton, was inhibited when the filtering food zooplankton were rich (Reynolds et al., 2002). Sampling stations (1\#, 2\# and 3\#) were located in the middle and upper reaches in the Harbin section of Songhua River recorded high relative biomass dominated by group X2 corresponding to low filtering food zooplankton (An et al., 2016; Feng, 2014). Group MP (mainly composed of Ulothris variabilis) was important corresponding to frequently disturbed, inorganic and turbid water areas. In autumn, the wind was strong, the river was disturbed frequently, and the turbidity increased obviously, which was beneficial to the growth of MP (Yang et al., 2014). Therefore, the relative biomass of group MP is not only more than $10 \%$ in summer and autumn, but also one of the dominant functional groups in autumn.

\section{Influence factors of water environment of Harbin section of Songhua River, Northeast China}

Any environmental factors needed for phytoplankton growth, including temperature, light intensity and hydrodynamics, could be the limiting factors influenced the growth of phytoplankton, and may also be the environmental influencing factor for the 
distribution of phytoplankton function groups (Xiao et al., 2011). The RDA analysis was used to explain clearly the relationship between crucial factors and phytoplankton functional groups and to further explore the driving factors changing the composition and distribution of phytoplankton functional group. The results of RDA analysis displayed that phytoplankton functional groups in the Harbin section of Songhua River were affected by $\mathrm{SD}, \mathrm{BOD}_{5}, \mathrm{Fe}^{3+}$, NTU, Chl-a, $\mathrm{COD}_{\mathrm{Mn}}, \mathrm{NH}_{4}{ }^{+}$and TP. Among them, SD was the key of environmental factors $(r=0.8729)$, which affected the change of functional groups throughout the year.

Studies of lakes and reservoirs in different regions of country showed that, such as Tianmu Reservoir of Shahe Reservoir located in north subtropical regions, Changshou Lake located in mid-subtropical regions, Yuqiao Reservoir located in warm temperate zone and Small Xingkai Lake located in temperate zone, SD was the main environmental factors influencing and changing the phytoplankton function groups (Cui et al., 2014; Yan et al., 2018; Liu et al., 2016; An et al., 2016). According to Cui et al. (2014), it was beneficial for phytoplankton growth to be in water bodies of low NTU and high SD, and it found a positive correlation between SD and the biomass of Bacillariophyta and Chrysophyta. Similarly, most of phytoplankton functional groups for this experiment were positive correlation with SD and negative correlation with NTU in the Harbin section of Songhua River. Li et al. (2013) also recorded that the water sediment content was high, SD was low and NTU was high in perennial water of Songhua River. Compared to other water bodies, SD in our research environment was remarkably lower. For instance, in Small Xingkai Lake located in Southeast Heilongjiang Province, An et al. (2016) recorded $0.46 \mathrm{~m}, 0.21 \mathrm{~m}$, and $0.21 \mathrm{~m}$ mean values of SD for spring, summer and autumn respectively. In Aha reservoir, one of the three drinking water sources in Guiyang, SD mean value in spring, summer and autumn was $0.90 \mathrm{~m}, 0.83 \mathrm{~m}$, and $1.19 \mathrm{~m}$, respectively (Li et al., 2015). According to Ostos et al. (2008), SD of El Gergal reservoir located in southwest Spain ranged from $0.2 \mathrm{~m}$ to $8.0 \mathrm{~m}$ and its mean was $1.77 \mathrm{~m}$ between 1979 and 2003. According to Chai et al. (2016), SD of Pearl River Estuary located in southern China ranged from $0.2 \mathrm{~m}$ to $3.2 \mathrm{~m}$ and its mean was $1.2 \mathrm{~m}$ in spring (March 2012) and ranged from $0.5 \mathrm{~m}$ to $2.0 \mathrm{~m}$ and its mean was $0.8 \mathrm{~m}$ in autumn (November 2011). There were many factors that limited SD, including not only phytoplankton, but also the concentration of sediment, the speed of FR, the amount of suspended solids and many other factors in the water (Pace et al., 1992). The faster FR will increase the suspended matter in the water, and the increase of sediment content will reduce the content of DO in the water. It was not simply to describe this with a single linear correlation (Pace et al., 1992).

Groups X2 were mainly comprised of minute-celled Chlamydomonas ovalis and Chroomonas acuta, and it was easier to be found it in waters with lower phosphorus levels (Laamanen, 1997). The study of Ma et al. (2019) also showed that group X2 with widely adaptability to nutrients was preferred to grow in slight alkaline water environment. We can see from the RDA biplot diagram in Figure 3, that groups X2 had a negative correlation with TP. On the one hand, the research of Siebielec et al. (2015) and da Silva and Fitzsimmons (2016) clearly proved that dissolved calcium ion will react with the phosphate in water forming insoluble calcium phosphate and other compounds that were not conducive to phytoplankton growth and propagation when the water environment was slight alkaline. On the other hand, the presence of large numbers of predators will reduce the number of filter feeders and the grazing pressure of filtering food zooplankton on group X2 (Padisak et al., 2009). Asplanchna priodonta, Polyarthra trigla and Synchaeta 
stylata were the dominant species (rotifer) found by Li et al. (2013) in Songhua River. Synchaeta stylata priodonta, as one kind of macrofilter-feeders, ate Dictyotaceae, filamentous algae, dinoflagellate, and other 20-50 $\mu \mathrm{m}$ zooplankton. Asplanchna and Polyarthra trigla, as group RC (predators), ate macroscopic algae, protozoa, rotifer and microcrustacea (Wen et al., 2017). It was more suitable for them to living in the alkaline water like the Songhua River with low temperature and high dissolved oxygen ( $\mathrm{Li}$ et al., 2013). A study even showed the number of filter feeders increased and the number of phytoplankton decreased when the SD exceeded $80 \mathrm{~cm}$ (Li and Li, 2001).

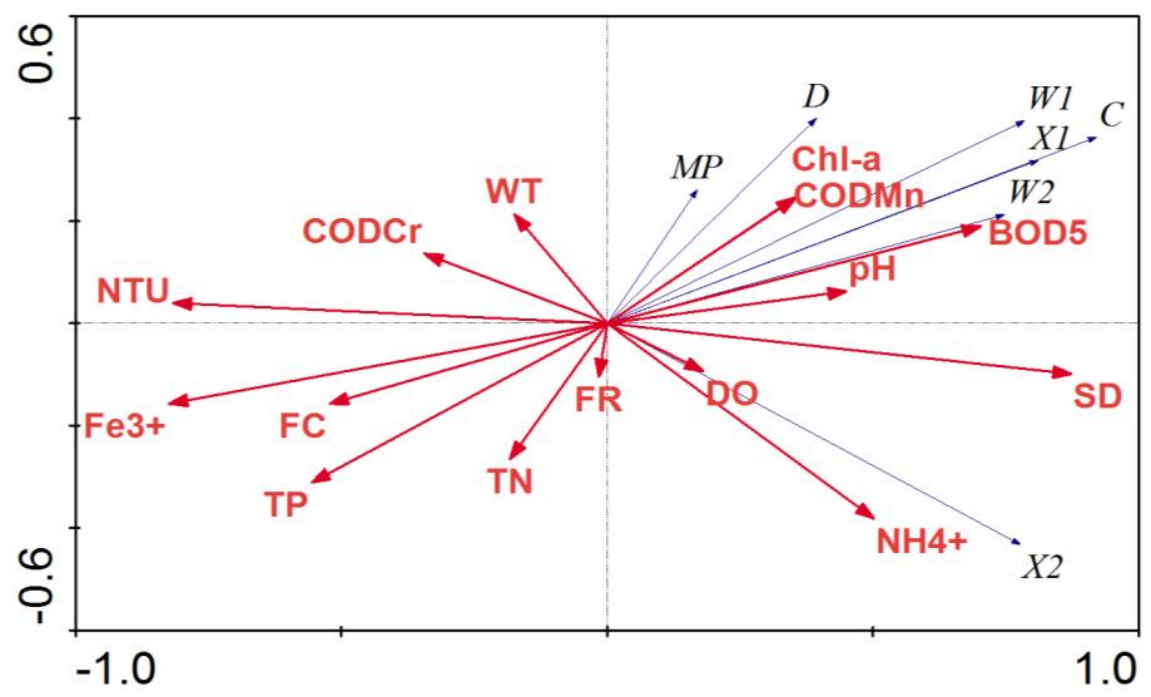

Figure 3. Correlation plots of the redundancy analysis (RDA) on the relationship between the environment variables and phytoplankton functional groups

Researchers had also noted that Chl-a, $\mathrm{COD}_{\mathrm{Mn}}, \mathrm{BOD}_{5}, \mathrm{Fe}^{3+}, \mathrm{NH}_{4}{ }^{+}$and $\mathrm{FC}$ were fundamental factors in shaping phytoplankton community composition. The study of Guo et al. (2020) in Xidayang Reservoir showed that phytoplankton density and biomass were significant positive correlation with $\mathrm{Chl}-\mathrm{a}$ and $\mathrm{COD}_{\mathrm{Mn}}(\mathrm{P}<0.05)$ and significantly negatively correlated with $\mathrm{NH}_{4}{ }^{+}(\mathrm{P}<0.05)$. Liu et al. (2014) pointed out that Chl-a, as the main pigment of phytoplankton photosynthesis, which growth was a significant positive predicator of the rapid growth of phytoplankton. In Muling River, the researchers analyzed the $\mathrm{COD}_{\mathrm{Mn}}$ was positively related with the predominant phytoplankton functional groups (Sun et al., 2019). In Dalian Songshu Reservoir, the researchers analyzed the $\mathrm{BOD}_{5}$ was positively related with the phytoplankton density (Yang, 2019). Arnaldo concluded that the growth rate of the dominant phytoplankton community structure limited by the concentration of $\mathrm{Fe}^{3+}$ in the upper waters layer of the Bransfield Strait in Antarctic Peninsula (D’Amaral et al., 2015). Similarly, from the RDA results, $\mathrm{BOD}_{5}$, Chl-a and $\mathrm{COD}_{\mathrm{Mn}}$ were positive correlated with the dominant functional groups, while $\mathrm{Fe}^{3+}$ and $\mathrm{NH}_{4}{ }^{+}$were negatively correlated with the dominant functional groups. Under the same experimental conditions, Mao et al. (1998) monitored the effect of phytoplankton with different densities or community composition on the amount of FC in the culture ponds. It was proved that there was a restrictive relationship between phytoplankton community composition and FC population. FC will release non-specific antibiotics substances to kill algae cells. When the amount of FC in the culture ponds was reduced, the densities of phytoplankton 
continued to increase within $24 \mathrm{~h}$. Same as the results in this experiment, the growth of FC and the biomass of phytoplankton had a negative correlation.

\section{Conclusions}

In this current study, a total of 84 species of phytoplankton species belonging to 16 functional groups (C, D, F, G, H1, J, L0, MP, P, S1, TB, W1, W2, X1, X2 and Y) were identified in the Harbin section of Songhua River, northeast China. There were 7 dominant functional groups: C, D, MP, W1, W2, X1 and X2. The seasonal dominant functional group succession: $\mathrm{X} 2 / \mathrm{C} \quad$ (spring) $\rightarrow \mathrm{X} 2 / \mathrm{C} / \mathrm{MP} \quad$ (summer) $\rightarrow \mathrm{X} 2 / \mathrm{C} / \mathrm{X} 1 / \mathrm{MP}$ (autumn). The result of one-way ANOVA test and RDA showed that WT, SD, NTU, Chla, $\mathrm{DO}, \mathrm{BOD}_{5}, \mathrm{NH}_{4}^{+}$, TP and $\mathrm{Fe}^{3+}$ were the major factors that influencing phytoplankton functional groups in the Harbin section of Songhua River, northeast China. RDA result revealed that SD and Chl-a were positive correlated with the dominant functional groups, while NTU and TP were negatively correlated with the dominant functional groups. This study revealed that the phytoplankton functional groups followed certain predictable pattern in the seasonal and spatial gradient. It could be useful for assessing and predicting the growth and development of phytoplankton in the future. At the same time, these environmental factors can also be considered as an important basis for the management and protection of rivers in northeast China for future studies.

\section{REFERENCES}

[1] An, R., Wang, F. Y., Yu, H. X., Ma, C. X. (2016): Characteristics and physical factors of phytoplankton functional groups in Small Xingkai Lake. - Research of Environmental Sciences 7: 985-994.

[2] Bohnenberger, J. E., Rodrigues, L. R., Mottamarques, D. D., Crossetti, L. O. (2018): Environmental dissimilarity over time in a large subtropical shallow lake is differently represented by phytoplankton functional approaches. - Mar. Freshw. Res 69: 95-104.

[3] Chai, C., Jiang, T., Cen, J. Y., Ge, W., Lu, S. H. (2016): Phytoplankton pigments and functional community structure in relation to environmental factors in the Pearl River Estuary. - Oceanologia 3: 201-211.

[4] Chuo, M., Ma, J., Liu, D., Yang, Z. (2019): Effects of the impounding process during the flood season on algal blooms in Xiangxi Bay in the Three Gorges Reservoir, China. Ecol. Model 392: 236-249.

[5] Crossetti, L. O., Becker, V., Cardoso, L. D. S., Rodrigues, L. R., Da Costa, L. S., Da Motta Marques, D. (2013): Is phytoplankton functional classification a suitable tool to investigate spatial heterogeneity in a subtropical shallow lake? - Limnologica 43: 157163.

[6] Cui, Y., Zhu, G. W., Li, H. Y., Chen, W. M., Zhou, W. P. (2014): Spatial and Temporal Distribution Characteristics of Water Quality in Shahe Reservoir within Tianmuhu Reservoir and its Relationship with Phytoplankton Community. - Journal of Hydroecology 3: 10-18.

[7] Cupertino, A., Gücker, B., Rückert, G. V., Figueredo, C. C. (2019): Phytoplankton assemblage composition as an environmental indicator in routine lentic monitoring: taxonomic versus functional groups. - Ecol. Indicat 101: 522-532.

[8] da Silva, C. B., Fitzsimmons, K. (2016): The effect of p H on phosphorus availability and speciation in an aquaponics nutrient solution. - Bioresour Technol 219: 778-781.

[9] D'Amaral, P. G. R. A., de Souza, M. S., Borges, M. C. R., Jesus, B., Tavano, V. M., Garcia, C. A. E. (2015): Photophysiological effects of Fe concentration gradients on 
diatom-dominated phytoplankton assemblages in the Antarctic Peninsula region. Journal of Experimental Marine Biology and Ecology 466: 49-58.

[10] Feng, Y. M. (2014): Zooplankton Community Structure and Analysis of Correlations with Environmental Factors in Xiaoingkai Lake. - Northeast Forestry University, Heilongjiang Province, China.

[11] Gafan, G. P., Lucas, V. S., Roberts, G. J., Petrie, A., Wilson, M., Spratt, D. A. (2005): Statistical analyses of complex denaturing gradient gel electrophoresis profiles. - Journal of Clinical Microbiology 8: 3971-3978.

[12] Guo, N. N., Li, D. D., Chen, X., Qi, Y. K., Song, C., Fan, L. M., Xi, L. P., Meng, S. L., Chen, J. Z. (2020): Structural community of phytoplankton species in the Xidayang reservoir repair demonstration area during the spring and autumn. - Journal of Dalian Fisheries University. https://doi.org/10.16535/j.cnki.dlhyxb.2019-235.

[13] Heebert, M. P., Beisner, B. E., Maranger, R. (2016): A meta-analysis of zooplankton functional traits influencing ecosystem function. - Ecology 4: 1069-1080.

[14] Hong, L. V., Yang, J., Liu, L. M., Yu, X. Q., Yu, Z., Chiang, P. (2014): Temperature and nutrients are significant drivers of seasonal shift in phytoplankton community from a drinking water reservoir, subtropical China. - Environ. Sci. Pollut. Res 21: 5917-5928.

[15] Hu, H. J., Wei, Y. X. (2006): The Freshwater Algae of China: Systematics, Taxonomy and Ecology. - Science Press, Beijing.

[16] Hustedt, F. (1930): Bacillariophyta (Diatomeae). - In: Pascher, A. (ed.) Die Süsswasser Flora Mitteleuropas. GFV, Jena.

[17] Huszaret, V. L. M., Nabout, J. C., Appel, M. O., Santos, J. B. O., Abe, D. S., Silva, L. H. S. (2015): Environmental and not spatial processes (directional and non-directional) shape the phytoplankton composition and functional groups in a large subtropical river basin. - J. Plankton Res 660: 1190-1200.

[18] Jongman, R. H. G., ter Braak, C. J. F., van Tongeren, O. F. R. (1987): Data Analysis in Community and Landscape Ecology. - Pudoc, Wageningen.

[19] Kim, H. G., Hong, S., Kim, D. K., Joo, G. J. (2020): Drivers shaping episodic and gradual changes in phytoplankton community succession: taxonomic versus functional groups. Science of the Total Environment 734: https://doi.org/10.1016/j.scitotenv.2020.138940.

[20] Klug, J. L., Cottingham, K. L. (2001): Interactions among environmental drivers: community responses to changing nutrients and dissolved organic carbon. - Ecology 82: 3390-3403.

[21] Komarek, J. (1983): Chlorophyceae (Grunalgen). Ordnung: Chlorococcales. - Die Binnengewasser 16.

[22] Kruk, C., Mazzeo, N., Lacerot, G., Reynolds, C. S. (2002): Classification schemes for phytoplankton: a local validation of a functional approach to the analysis of species temporal replacement. - J. Plankton Res 24: 901-912.

[23] Laamanen, M. J. (1997): Environmental factors affecting the occurrence of different morphological forms of cyanoprokaryotes in the northern Baltic Sea. - J Plankton Res. 10: 1385-1403.

[24] Lampitt, R. S., Wishner, K. F., Turley, C. M., Angel, M. V. (1993): Marine snow studies in the Northeast Atlantic Ocean: distribution, composition and role as a food source for migrating plankton. - Mar Biol 4: 689-702.

[25] Lange-Bertalot, H. (2001): Diatoms of Europe: Diatoms of the European Inland Waters. Gantner Verlag, Koenigstein.

[26] Li, L., Li, Q. H., Jiao, S. L., Li, Y., Deng, L., Sun, R. G., Gao, Y. C., Luo, L. (2015): Spatial and temporal distribution characteristics of phytoplankton functional groups in aha reservoir and their influencing factors. - Acta Scientiae Circumstantiae 11: 36043611.

[27] Li, L., Li, Q., Chen, J., Wang, J., Jiao, S., Chen, F. (2017): Temporal and spatial distribution of phytoplankton functional groups and role of environment factors in a deep subtropical reservoir. - Chinese J Oceanol Limnol 3: 761-771. 
[28] Li, X. Y., Yu, H. X., Ma, C. X. (2013): Structure of phytoplankton community based on canonical correspondence analysis and biodiversity analysis in Harbin section of Songhua river. - Journal of Northeast Forestry University 10: 103-107.

[29] Li, Y. H., Li, B. C. (2001): Spending the Winter by observing water change and its biological analysis. - Fisheries Science 4: 38-41.

[30] Liu, F. F., Su, J., Moll, A., Krasemann, H., Chen, Xueen., Pohlmann, Thomas., Wirtz, Kai. (2014): Assessment of the summer-autumn bloom in the Bohai Sea using satellite images to identify the roles of wind mixing and light conditions. - Journal of Marine Systems 129: 303-317.

[31] Liu, X. B., Nie, Y., Zhao, X. G., Liu, Q. (2016): A correlation analysis of the phytoplankton community and environment factors in the Yuqiao Reservoir in spring and summer of 2014. - Environmental Monitoring in China 32: 64-67.

[32] Lopes, M. R. M., Bicudo, C. E. M., Ferragut, M. C. (2005): Short term and temporal variation of phytoplankton in a shallow tropical oligotrophic reservoir, southeast Brazil. Hydrobiologia 542: 235-247.

[33] Ma, C. X., Yin, Z. L., Yu, H. X. (2016): Seasonal dynamics characteristics and physical factors of phytoplankton functional groups in Sanhuanpao wetland reserve. - Journal of Northeast Forestry University 11: 45-51.

[34] Ma, C. X., Mwagona, P. C., Yu, H. X., Sun, X. W., Liang, L. Q., Shahid, M. (2019): Spatial and temporal variation of phytoplankton functional groups in extremely alkaline Dali Nur Lake, North China. - Journal of Freshwater Ecology 1: 91-105.

[35] Maggio, J., Fernandez, C., Parodi, E. R., Diaz, M. (2016): Modeling phytoplankton community in reservoirs. A comparison between taxonomic and functional groups-based models. - J. Environ. Manag 165: 31-52.

[36] Mao, Z. J., Chen, C. F. (1998): A preliminary study on the relationship between phytoplankton and bacteria in culture ponds. - Reservoir Fisheries 05: 17-20.

[37] MEP (Ministry of Environmental Protection) China (2006): China's National Standard: GB/T5750-2006. Environmental Quality Standards for Surface Water. - Ministry of Environmental Protection. China Standards Press, Beijing.

[38] Mwagona, P. C., Ma, C. X., Yu, H. X. (2018): Seasonal dynamics of zooplankton functional groups in relation to environmental variables in Xiquanyan reservoir, Northeast China. - Annales de Limnologie - International Journal of Limnology 54: 33.

[39] Ostos, E. M., Pizarro, L. C., Basanta, A. B., George, D. G. (2008): The spatial distribution of different phytoplankton functional groups in a Mediterranean reservoir. Aquat Ecol 42: 115-128.

[40] Pace, M. L., Findlay, S., Lints, D. (1992): Zooplankton in advective environments: the Hudson River community and a comparative analysis. - Fisheries and Aquatic Sciences 5: 1060-1069.

[41] Padisak, J., Crossetti, L. O., Naselli-Flores, L. (2009): Use and misuse in the application of the phytoplankton functional classification: a critical review with updates. Hydrobiologia 1: 1-19.

[42] Patrick, R., Reimer, C. W. (1966): The Diatoms of the United States. - Monographs Philadelphia. Academy of Natural Sciences of Philadelphia.

[43] Prescott, G. W. (1954): How to Know the Fresh-Water Algae: An Illustrated Key for Identifying the More Common Fresh-Water Algae to Genus, with Hundreds of Species Named Pictured and with Numerous Aids for Their Study. Vol.1. - W. C. Brown Company, Dubuque, Iowa.

[44] Qiu, X. C., Hao, H. X., Sun, X. X. (2012): Relationships between zooplankton and water environmental factors in Shahu Lake, Ningxia of Northwest China: a multivariate analysis. - Chinese Journal of Ecology 4: 896-901.

[45] Qu, Y., Wu, N., Guse, B., Makarevi ciute, K., Sun, X., Nicola, F. (2019): Riverine phytoplankton functional groups response to multiple stressors variously depending on hydrological periods. - Ecol. Indicat 101: 41-49. 
[46] Reynolds, C. S. (2006): The Ecology of Phytoplankton: Ecology, Biodiversity and Conservation. - Cambridge University Press, Cambridge, UK.

[47] Reynolds, C. S., Huszar, V., Kruk, C., Naselli-Flores, L., Melo, S. (2002): Towards a functional classification of the freshwater phytoplankton. - Journal of Plankton Research 5: 417-428.

[48] Siebielec, G., Ukalska-Jaruga, A., Kidd, P. (2015): Bioavailability of Trace Elements in Soils Amended with High-Phosphate Materials. Phosphate in Soils: Interaction with Micronutrients, Radionuclides Heavy Metals. Vol. 2. - CRC Press, Boca Raton, FL.

[49] Su, M., Andersen, T., Burch, M., Jia, Z., An, W., Yu, J., Yang, M. (2019): Succession and interaction of surface and subsurface cyanobacterial blooms in oligotrophic/mesotrophic reservoirs: a case study in Miyun Reservoir. - Sci. Total Environ 649: 1553-1562.

[50] Sun, X., Mwagona, P. C., Isaac, E. S., Hou, W. J., Li, X. Y., Zhao, F., Chen, Q., Zhao, Y. X., Liu, D., Li, X. C., Ma, C. X., Yu, H. X. (2019): Phytoplankton functional groups response to environmental parameters in Muling River basin of northeast China. Annales de Limnologie - International Journal of Limnology 55: 17.

[51] ter Braak, C. J. F. (1988): CANOCO-A FORTRAN Program for Canonical Ordination by Partial Detrended (Canonical) Correspondence Analysis, Principal Components Analysis and Redundancy Analysis (Version 2.1). - Agricultural Mathematics Group, Wageningen.

[52] ter Braak, C. J. F. (1990): Update Notes. CANOCO (Version 3.1). - Agricultural Mathematics Group, Wageningen.

[53] ter Braak, C. J. F. (1994): Canonical community ordination. Part I: Basic theory and linear methods. - Ecoscience 1: 127-140.

[54] ter Braak, C. J. F., Smilauer, P. (1998): CANOCO Reference Manual and User's Guide to CANOCO for Windows: Software for Canonical Community Ordination (version 4). Microcomputer Power, Ithaca.

[55] Utermöhl, H. (1958): Zur Vervollkommnung der quantitativen Phytoplankton-Methodik. - Internationale Vereinigung für Theoretische und Angewandte Limnologie 9: 1-38.

[56] Wang, Y. J., Cai, Y. P., Yin, X. N., Yang, Z. F. (2020): Succession of phytoplankton functional groups in Macau's two shallow urban border reservoirs under multiple changing factors. - Journal of Cleaner Production 264: 121553.

[57] Wen, X. L., Xie, P., Zhou, J., Xi, Y. L. (2017): Reponses of the annual dynamics of functional feeding groups and dominant populations of rotifers to environmental factors in Lake Tingtang. - Acta Ecologica Sinica 23: 8029-8038.

[58] Xiao, L. J., Wang, T., Hu, R., Han, B. P., Wang, S., Qian, X., Padisák, J. (2011): Succession of phytoplankton functional groups regulated by monsoonal hydrology in a large canyon-shaped reservoir. - Water Research 45: 5099-5109.

[59] Xu, Z. L., Chen, Y. Q. (1989): Aggregated intensity of dominant species of zooplankton in autumn in the East China Sea and Yellow Sea. - Journal of Ecology 4: 13-19.

[60] Yan, Q. (2011): Study on the Community Structure of Phytoplankton and Environmental Impact Assessment in Harbin Section of Songhua River. - Northeast Forestry University, Heilongjiang Province, China.

[61] Yan, S. S., Lei, B., Liu, S. R., Yang, C. H., Xie, G. X. (2018): Seasonal variation of phytoplankton functional groups in Changshou Lake and relevant environmental factors. - Journal of Hydroecology 3: 52-60.

[62] Yang, R. F. (2019): Phytoplankton characteristics and response to environmental factors in Dalian Songshu Reservoir. - Soil and Water Conservation in China 07: 34-37.

[63] Yang, W., Zhu, J. Y., Lu, K. H., Wan, L., Mao, X. H. (2014): The establishment, development and application of classification approach of freshwater phytoplankton based on the functional group: a review. - Chinese Journal of Applied Ecology 6: 18331840 . 


\section{APPENDIX}

Table A1. Environmental parameters in each season in the Harbin section of Songhua River, Northeast China

\begin{tabular}{|c|c|c|c|c|c|c|c|c|c|c|c|c|c|c|c|}
\hline & $\begin{array}{l}\text { WT } \\
\left({ }^{\circ} \mathrm{C}\right)\end{array}$ & pH & $\begin{array}{c}\text { FR } \\
(\mathbf{m} / \mathbf{s})\end{array}$ & $\begin{array}{l}\text { SD } \\
(\mathbf{m})\end{array}$ & NTU & $\begin{array}{l}\text { Chl-a/ } \\
\text { (ug/L) }\end{array}$ & $\begin{array}{c}\text { DO } \\
(\mathrm{mg} / \mathrm{L})\end{array}$ & $\begin{array}{c}\text { CODMn } \\
(\mathrm{mg} / \mathrm{L})\end{array}$ & $\begin{array}{c}\text { CODCr } \\
(\mathrm{mg} / \mathrm{L})\end{array}$ & $\begin{array}{l}\text { BOD5 } \\
(\mathrm{mg} / \mathrm{L})\end{array}$ & $\begin{array}{l}\text { NH4+ } \\
(\mathrm{mg} / \mathrm{L})\end{array}$ & $\begin{array}{c}\text { TP } \\
(\mathrm{mg} / \mathrm{L})\end{array}$ & $\begin{array}{c}\text { TN } \\
(\mathrm{mg} / \mathrm{L})\end{array}$ & $\begin{array}{c}\text { FC } \\
(\mathrm{mg} / \mathrm{L})\end{array}$ & $\begin{array}{c}\mathrm{Fe3+} \\
(\mathrm{mg} / \mathrm{L})\end{array}$ \\
\hline Spring1\# & 17.50 & 7.85 & 1.26 & 58.50 & 7.55 & 8.85 & 7.30 & 5.04 & 12.70 & 5.80 & 0.72 & 0.07 & 3.00 & 24196.00 & 0.12 \\
\hline Spring2\# & 18.00 & 7.88 & 0.83 & 48.00 & 10.00 & 12.25 & 7.00 & 6.00 & 12.40 & 4.30 & 0.83 & 0.10 & 3.32 & 24196.00 & 0.22 \\
\hline Spring3\# & 17.80 & 7.85 & 0.28 & 32.00 & 23.80 & 15.20 & 7.50 & 5.20 & 12.20 & 5.70 & 0.50 & 0.09 & 1.42 & 12997.00 & 0.10 \\
\hline Spring4\# & 18.10 & 7.99 & 0.39 & 31.50 & 15.15 & 19.75 & 7.00 & 5.84 & 12.20 & 5.60 & 0.63 & 0.10 & 2.20 & 24196.00 & 0.15 \\
\hline Spring5\# & 18.50 & 7.83 & 0.57 & 34.50 & 15.30 & 15.30 & 7.90 & 7.28 & 12.70 & 5.30 & 0.09 & 0.06 & 1.68 & 754.00 & 0.12 \\
\hline Spring6\# & 18.40 & 8.21 & 0.18 & 32.00 & 18.30 & 20.90 & 8.60 & 5.52 & 11.60 & 3.50 & 0.08 & 0.04 & 1.01 & 24196.00 & 0.23 \\
\hline Spring7\# & 18.50 & 8.31 & 1.89 & 29.00 & 24.60 & 21.10 & 7.70 & 5.84 & 13.00 & 4.80 & 0.11 & 0.06 & 1.61 & 393.00 & 0.22 \\
\hline Spring8\# & 13.60 & 6.95 & 0.41 & 34.50 & 12.55 & 0.80 & 9.75 & 3.76 & 11.20 & 2.90 & 0.48 & 0.04 & 2.18 & 1474.00 & 0.32 \\
\hline Summer1\# & 22.37 & 7.57 & 0.70 & 11.50 & 145.35 & 7.15 & 6.43 & 5.65 & 11.37 & 3.30 & 0.23 & 0.12 & 2.26 & 34305.00 & 1.00 \\
\hline Summer2\# & 22.93 & 7.58 & 0.87 & 11.50 & 170.30 & 10.05 & 5.93 & 5.23 & 13.20 & 3.53 & 0.25 & 0.12 & 2.17 & 36593.00 & 0.92 \\
\hline Summer3\# & 22.80 & 7.38 & 0.63 & 12.00 & 101.60 & 8.40 & 4.70 & 4.88 & 14.10 & 1.80 & 0.12 & 0.10 & 3.04 & 48392.00 & 0.64 \\
\hline Summer4\# & 23.30 & 7.64 & 0.64 & 10.50 & 157.65 & 8.45 & 6.63 & 4.85 & 13.27 & 3.73 & 0.38 & 0.11 & 2.01 & 28283.00 & 0.99 \\
\hline Summer5\# & 23.20 & 7.57 & 1.50 & 11.50 & 152.15 & 9.65 & 7.07 & 6.13 & 11.80 & 2.97 & 0.08 & 0.08 & 1.89 & 15291.00 & 1.28 \\
\hline Summer6\# & 23.10 & 7.34 & 1.05 & 11.00 & 146.70 & 8.90 & 6.20 & 4.56 & 14.10 & 1.70 & 0.08 & 0.09 & 2.90 & 17328.00 & 1.08 \\
\hline Summer7\# & 23.37 & 7.74 & 1.50 & 13.00 & 157.30 & 9.20 & 7.07 & 4.85 & 13.37 & 3.03 & 0.09 & 0.11 & 1.94 & 18975.00 & 1.20 \\
\hline Summer8\# & 22.10 & 7.88 & 0.84 & 10.50 & 97.00 & 2.35 & 8.80 & 6.51 & 13.47 & 3.63 & 0.22 & 0.06 & 1.88 & 11112.00 & 0.69 \\
\hline Autumn1\# & 14.55 & 7.73 & 0.23 & 19.00 & 30.30 & 6.05 & 8.60 & 4.56 & 14.00 & 2.20 & 0.19 & 0.08 & 2.05 & 36294.00 & 0.61 \\
\hline Autumn2\# & 14.35 & 7.72 & 0.29 & 19.00 & 34.60 & 5.65 & 8.75 & 4.48 & 12.95 & 2.05 & 0.23 & 0.16 & 1.84 & 32860.00 & 1.56 \\
\hline Autumn3\# & 14.50 & 7.78 & 0.29 & 20.00 & 47.50 & 6.80 & 9.30 & 3.76 & 11.80 & 2.60 & 0.07 & 0.14 & 1.70 & 17329.00 & 0.56 \\
\hline Autumn4\# & 14.75 & 7.68 & 0.66 & 12.50 & 64.65 & 6.75 & 8.75 & 5.36 & 10.60 & 2.95 & 0.16 & 0.19 & 1.86 & 36294.00 & 1.64 \\
\hline Autumn5\# & 14.90 & 7.63 & 0.45 & 14.00 & 49.45 & 8.65 & 8.75 & 5.20 & 13.55 & 2.90 & 0.09 & 0.15 & 1.89 & 11857.00 & 1.64 \\
\hline Autumn6\# & 14.00 & 7.84 & 0.94 & 18.00 & 46.80 & 7.30 & 9.40 & 4.08 & 11.50 & 2.30 & 0.07 & 0.17 & 1.72 & 4106.00 & 0.76 \\
\hline Autumn7\# & 15.10 & 7.77 & 0.29 & 20.00 & 45.40 & 6.20 & 8.75 & 5.04 & 12.95 & 1.55 & 0.18 & 0.17 & 1.82 & 13252.00 & 1.63 \\
\hline Autumn8\# & 14.00 & 7.59 & 0.47 & 25.50 & 32.50 & 0.45 & 8.90 & 4.72 & 12.85 & 1.95 & 0.09 & 0.16 & 1.79 & 29671.00 & 1.40 \\
\hline
\end{tabular}

